\title{
Phyto-Cleaning of Particulate Matter from Polluted Air by Woody Plant Species in the Near-Desert City of Jodhpur (India) and the Role of Heme Oxygenase in Their Response to PM Stress Conditions
}

Robert Popek ( $\sim$ robert_popek@sggw.edu.pl)

Warsaw University of Life Sciences: Szkola Glowna Gospodarstwa Wiejskiego w Warszawie https://orcid.org/0000-0001-6112-841X

Lovely Mahawar

University of Jodhpur: Jai Narain Vyas University

Gyan Singh Shekhawat

Jodhpur University: Jai Narain Vyas University

Arkadiusz Przybysz

Warsaw University of Life Sciences: Szkola Glowna Gospodarstwa Wiejskiego w Warszawie

\section{Research Article}

Keywords: air, heavy metals, heme oxygenase, particular matter, phytoremediation

Posted Date: September 29th, 2021

DOI: https://doi.org/10.21203/rs.3.rs-808177/v1

License: (c) (1) This work is licensed under a Creative Commons Attribution 4.0 International License. Read Full License 


\section{Abstract}

Particulate matter (PM) is one of the most dangerous pollutants in the air. Urban vegetation, especially trees and shrubs, accumulate PM and reduce its concentration in ambient air. The aim of this study was to examine 10 tree and shrub species common for the Indian city of Jodhpur (Rajasthan) located on the edge of the Thar Desert and determine: (1) the accumulation of surface and in-wax PM (both in three different size fractions), (2) the amount of epicuticular waxes on foliage, (3) the concentrations of heavy metals ( $\mathrm{Cd}$ and $\mathrm{Cu}$ ) on/in the leaves of the examined species, and (4) the level of heme oxygenase enzyme in leaves that accumulate PM and heavy metals. Among the investigated species, F. religiosa and C. myxa accumulated the greatest amount of total PM. F. religiosa is a tall tree with a lush, large crown and leaves with wavy edge, convex veins and long petioles, while C. myxa have hairy leaves with convex veins. The lowest PM accumulation was recorded for drought resistant S. persica and A. indica, which is probably due to their adaptation to growing conditions. Heavy metals ( $\mathrm{Cu}$ and $\mathrm{Cd}$ ) were found in the leaves of almost every examined species. The accumulation of heavy metals (especially $\mathrm{Cu}$ ) was positively correlated with the amount of PM deposited on the foliage. A new finding of this study indicated a potentially important role of $\mathrm{HO}$ in the plants' response to PM-induced stress. The correlation between $\mathrm{HO}$ and PM was stronger than that between $\mathrm{HO}$ and $\mathrm{HMs}$. The results obtained in this study emphasise the role of plants in cleaning polluted air in conditions where there are very high concentrations of PM.

\section{Introduction}

Atmospheric particle pollution is among the greatest challenges faced in urban areas. One of the most dangerous pollutants in the air is particulate matter (PM) (OECD 2012; WHO 2020), which is microscopic particles of different composition and origin (Han et al. 2020; Weuve et al. 2012). In the northern part of the Indian subcontinent, the most common PM is mineral dust from the Thar Desert, around half of which is large PM (50\%) (Gobbi et al. 2000 ; Sarkar et al. 2019). These particles are also known to be rich in nitrates that a photo-induced "re-noxification" process converts into NOx (Ndour et al. 2009). Nevertheless, in this region, the most problematic and dangerous PM is generated by human activity in the form of energy production, vehicular transportation and construction (Chernysheva et al. 2018). It comprises a mixture of trace elements, black carbon, dibenzofurans, polychlorinated biphenyls (PCBs) and polycyclic aromatic hydrocarbons (Alghamdi 2016; Łukowski et al. 2018). PM of all types is often suspended in the air for weeks and travels great distances, even between continents (Lin et al. 2014).

PM can enter the human body via the respiratory tract and is harmful to human health (Jędrychowski et al. 2015). Long-term exposure to airborne PM causes severe respiratory disorders, such as breathing difficulties, worsening asthma symptoms and chronic bronchitis, as well as diseases that affect all segments of the community such as cardiopulmonary diseases and lung cancer (Hsu et al. 2015; Kim et al. 2015; Saravia et al. 2013). Outdoor air pollution, mainly $\mathrm{PM}_{2.5}$ (PM particles less than $2.5 \mu \mathrm{m}$ ) caused 4.2 million premature deaths worldwide in 2016 (WHO 2017). After Bangladesh, India is the country with the most polluted air. New data reveal that air pollution shortens the average Indian lifespan by 5.2 years and average PM concentration in the country has risen by approximately 42 \% since 1998 (Greenstone and Fan 2020). Today, almost the entire Indian population is exposed to levels of PM that exceed WHO guidelines (WHO 2020).

Plants, especially trees and shrubs, play an important role in the adsorption and reduction of PM concentrations in the air ( tukowski et al. 2020; Popek et al. 2015; Pugh et al. 2012). They are effective at accumulating PM on the surface of leaves, stems and bark, while being eco-friendly and in line with public needs (Popek et al. 2017). However, the ability to capture PM on leaves is strongly linked to the characteristics of the species (Jouraeva et al. 2002; Sæb $\varnothing$ et al. 2012). Plant shape and porosity (Leonard et al. 2016), leaf surface morphology, the complexity of the layer of cuticular waxes, the arrangement of stomata and the presence of trichomes on leaves (Dzierżanowski et al. 2011; Haynes et al. 2019; Prusty et al., 2005) are very important. Urban greenery is able to remove significant amounts of pollutants from the air in cities (Kroeger et al. 2018; Pugh et al. 2012; Vailshery et al. 2013; Yang et al. 2005), and therefore air phytoremediation is becoming increasingly popular worldwide, especially as it does not involve any tangible costs (Paton-Walsh et al. 2019).

Unfortunately, the accumulated PM has a negative impact on plants, including trees and shrubs (Li et al. 2019; Mina et al. 2018; Popek et al. 2018a; Siqueira-Silva et al. 2016; Singh et al. 2019; Zhou et al. 2018). The PM aerosols can exert climatic effects by absorption and scattering of solar radiation, and cloud condensation nuclei activity (Luo et al. 2019). PM accumulated on the surface of foliage changes its optical properties due to the absorption/reflection of photosynthetic active radiation (PAR) or clogging/damage to stomata (Li et al. 2019; Singh et al. 2019). Jin et al. (2021) report that PM adsorbed on leaves is usually concentrated in the stomata or the corrugated areas around the stomata, and PM up to $2 \mu \mathrm{m}$ can enter or block the stomata. As a result, gas exchange and the intensity of photosynthesis and transpiration are much less efficient (Li et al. 2019; Mina et al. 2018; Popek et al., 2018b). The PM may include toxic substances, such as heavy metals (HM) or organic pollutants, which can penetrate from the leaf surface to the inner plant tissues (Luo et al. 2019; Przybysz et al. 2019). There are growing reports that PM induces oxidative stress (Ghorbanli et al. 2007; Mudway et al. 2020; Piacentini et al. 2019). Prolonged exposure to higher concentrations of PM may cause different morphoanatomical (decreased plant biomass and height, disturbance in plant development, leaf chlorosis and necrosis, leaf thickness alteration, modification of the structure and chemical composition of waxes, cell turgor loss and cellular collapse) and physiological (decreased photosynthetic pigments and leaf water content, increased leaf temperature, nutritional alteration in leaflets, and early leaf senescence and abscission) alterations in foliage (Mina et al. 2018; Siqueira-Silva et al. 2016; Zhou et al. 2018). In addition, $\mathrm{PM}$ can change the $\mathrm{pH}$ and chemical composition of the soil and indirectly affect plant performance (Luo et al. 2019; Piacentini et al. 2019; Siqueira-Silva et al. 2016).

Plants growing in an environment with a polluted atmosphere are characterised by various modifications that enable them to survive in difficult growing conditions. Changes may relate to the frequency, density, location and size of the stomata (Gostin 2009; Kiyomizu et al. 2019). In order to protect gas exchange from the adverse effects of PM, smaller stomata are located on the abaxial side of the leaf (Gostin 2009; Li et al. 2019). Some species increase mesophyll thickness at sites with high pollution, which may decrease the flux of air pollutants inside leaves and thus the uptake of air pollutants by leaf tissues (Kiyomizu et al. 2019). Leaf trichomes and grooves appear to have a role in protecting plants from PM exposure (Li et al. 2019). The higher groove 
proportion and presence of trichomes on the leaf surface absorbs some PM and buffers its negative effect on stomata (Li et al. 2019). Air pollutants accumulated on plant foliage may also be mitigated by phyllosphere microbes (Wei et al. 2017). To counteract the oxidative stress induced by PM, plants increase the activity of the antioxidant system, including enzymes such as peroxidase and catalase (Ghorbanli et al. 2007; Mudway et al. 2020).

As mentioned above, atmospheric PM often contains heavy metals (Ghasemi et al. 2020). A considerable quantity of atmospheric heavy metals is absorbed via the foliar organs of plants after the wet or dry deposition of atmospheric fallouts on the plant canopy (; Liu et al. 2019; Przybysz et al. 2019; Shahid et al. 2017). Heavy metal uptake from the air greatly depends on a number of factors, including the physico-chemical characteristics of the cuticle and metals, the chemical and physical forms of the adsorbed metal, the morphology and surface area of the plant leaves, the surface texture of leaves (pubescence and roughness), exposure duration, environmental conditions, plant gas exchange, concentrations of atmospheric PM, and PM size, load and composition (Shahid et al. 2017; Sharma et al. 2020). Not all airborne heavy metals are immobilised on the foliage surface; some heavy metals linked to PM can enter plant leaf tissues and can be translocated to the stem below and roots through the vascular sap (Sharma et al. 2020; Uzu et al. 2010). The concentrations of heavy metals in the foliage of plants growing close to the emission source are usually high (Mori et al. 2015; Noh et al. 2019; Zhu et al. 2019). The considerable accumulation of heavy metals derived from PM is due to the direct transfer of contaminants from the atmosphere to foliar organs but also due to the atmosphere-soil-root transfer (Liu et al. 2019). Heavy metals accumulated by plants disturb most physiological, metabolic and biochemical processes (Shahid et al. 2017).

One of the enzymes involved in plant responses to abiotic stress (including salt, UV light, drought and particularly oxidative stress and heavy metals) is heme oxygenase (HO) (Hancock and Russell 2021; He and He 2014; Mahawar et al. 2021; Wegiel et al. 2014). In plants (Arabidopsis thaliana L.), the HO family comprises four members that fall into two subfamilies: the HO1 subfamily (HO-1, HO-3, HO-4) and the HO2 subfamily (HO-2) (Fang et al. 2021). The catalytic action of HO-1 is the breakdown of heme. This is an oxygen-dependent reaction that uses NADPH as a cofactor and generates biliverdin, carbon monoxide (CO) and iron (Hancock and Russell 2021;Wilks 2002). This reaction is essential in physiological processes as diverse as iron reutilisation and cellular signalling in mammals, synthesis of essential light harvesting pigments (e.g. phytochrome chromophore formation) in cyanobacteria and higher plants, and the acquisition of iron by bacterial pathogens (Lecube et al. 2014; Wilks 2002). In plants, HO-1 is also associated with root development and crosstalk between NO, CO and hydrogen peroxide (Lecube et al. 2014). According to Lawal et al. (2015), in a human HO-1 protects endothelial cells from the toxicity of air pollutant chemicals.

Until now, city planners have selected plants for urbanised areas primarily on the basis of their decorative value and tolerance to urban abiotic stresses. Recent findings have led to consideration starting to be given to the ability of plants to purify ambient air from PM. Research on the phytoremediation properties of urban plants is being conducted worldwide. However, to date there is no universal formula for assessing whether a given species is useful for air phytoremediation and thus experiments should cover the widest possible number of species occurring under different climatic conditions. Therefore, the aim of this study was to examine 10 tree and shrub species recommended for planting in the Indian city of Jodhpur (Rajasthan) on the edge of the Thar Desert and determine: (1) the accumulation of surface and in-wax PM (both in three different size fractions), (2) the amount of epicuticular waxes on foliage, (3) the concentrations of heavy metals ( $\mathrm{Cd}$ and $\mathrm{Cu}$ ) on/in the leaves of the examined species, and (4) the level of heme oxygenase enzyme in leaves that accumulate PM and heavy metals.

\section{Materials And Methods}

\subsection{Study location}

The study took place in the city of Jodhpur in the botanical garden of Jai Narain Vyas University (JNVU). Jodhpur is the second largest city in the Indian state of Rajasthan and has a population of approximately 1.5 million people (Fig. 1). It is called the Gateway to Thar as it is located on the edge of the Thar Desert. Its many palaces, forts and temples make the city a popular tourist destination. The climate of Jodhpur is hot and semi-arid during its almost yearround dry season. The short rainy season runs from late June to September (average rainfall of around 362 millimetres). Temperature is routinely very high at around 40 to $45^{\circ} \mathrm{C}$ from March to October. During the rest of the year, it oscillates between $25^{\circ} \mathrm{C}$ and $30^{\circ} \mathrm{C}$.

Jodhpur is the most polluted city in the Rajasthan and has very poor air quality. According to the latest WHO data (2016), the annual mean concentrations of $\mathrm{PM}_{10}$ and $\mathrm{PM}_{2.5}$ are $180 \mathrm{ug} / \mathrm{m}^{3}$ and $98 \mathrm{ug} / \mathrm{m}^{3}$ respectively, and these are growing significantly each year. In critical situations, the concentrations of both fractions may even exceed $300 \mathrm{ug} / \mathrm{m}^{3}$ (WHO, 2020).

\subsection{Plant material and sample collection}

For the experiment, ten tree, shrub and climber species common to the Thar Desert region were selected: Azadirachta indica Juss., Bougainvillea spectabilis Willd., W. T. Aiton, Colophospermum mopane Kirk ex J. Léonard, Cordia myxa L., Eucalyptus globulus Labill., Ficus religiosa L., Polyalthia longifolia (Sonn.) Thwaites, Salvadora persica L., Tinospora cordifolia (Willd.) Hook. f. \& Thomson, and Vachellia nilotica (L.) P.J.H. Hurter \& Mabb. The plants had already been growing in-vivo in the JNVU's botanical garden. The location is in an area with few buildings and very little traffic. The nearest, very well-maintained road is about 500 metres from the garden's edge. The plants selected for the experiment were in good condition, i.e. healthy and free from pests.

The harvest of plant samples was preceded by several months of rainless weather, which limited the amount of PM washed off the foliage. Leaves were sampled in four biological replications (biological replication was individual tree/shrub/climber) in November 2017 ( $n=4$ samples $x \times 10$ species). A single sample consisted of leaves harvested from different parts of the plant. Samples were composed of three to seven leaves, depending on their size. In order to avoid the clogging of filters during the PM filtering process, the total area of each sample did not exceed $300 \mathrm{~cm}^{2}$. Each sample was placed in a paper envelope, labelled and transferred to a constant temperature and humidity test room where they were stored until analysis.

Page 3/14 


\subsection{Analysis of PM accumulation and amount of epicuticular waxes on leaves}

Accumulation of PM and the amount of epicuticular waxes on foliage were determined gravimetrically. The amount of PM was determined in two categories: surface PM ( $\left.{ }_{S} P M\right)$, which was washed off with water (in natural conditions it can be washed off from the foliage by rain), and in-wax PM ( $w P M)$, which was washed off with chloroform (PM immobilised in waxes). Both categories were analysed in three size fractions: 0.2-2.5, 2.5-10 and 10$100 \mu \mathrm{m})$. Leaf samples were first washed with distilled water and then with chloroform. The solutions obtained were then passed through a 100- $\mu \mathrm{m}$ mesh sieve (to remove particles larger than $100 \mu \mathrm{m}$ from the solution) and were then sequentially filtered using pre-weighed filters of type 91 (paper filter with a pore size of $10 \mu \mathrm{m}$ ), type 42 (paper filter with a pore size of $2.5 \mu \mathrm{m}$ ) and polytetrafluoroethylene (PTFE) membrane filters (a pore size of $0.2 \mu \mathrm{m})($ all Whatman, UK). After filtration, all the filters were weighed again. The quantity of epicuticular waxes was weighed after evaporation of the chloroform collected in pre-weighed beakers. The area of leaves from each sample was determined using a Plant Leaf Area Meter (Petiole, Ukraine). The amounts of PM from filters and waxes were then recalculated to give the $\mu \mathrm{g} \mathrm{cm}^{-2}$ of leaves (Dzierżanowski et al. 2011).

\subsection{Quantitative analysis of heavy metals in leaves}

Quantitative assessments of cadmium (Cd) and copper $(\mathrm{Cu})$ were performed for all the examined species. Amounts of HMs were measured in two replicates ( $n=2$ samples $\times 10$ species). Foliage, including accumulated PM (these samples were not used for PM analysis), was collected in the same way as previously described in 2.2. After harvest, the samples were dried at $105^{\circ} \mathrm{C}$ for $48 \mathrm{~h}$, then ground into a fine powder and placed in paper bags until analysis. Powdered plant material $\left(500 \mathrm{mg}\right.$ ) was digested with $9 \mathrm{~mL}$ of $65 \% \mathrm{v} / \mathrm{v} \mathrm{HNO}_{3}$ in Titan MPS (PerkinElmer, Waltham, USA) and diluted to $50 \mathrm{~mL}$. Samples were then analysed with the high-resolution ICP-OES technique using an Optima 8000 spectrometer (PerkinElmer, Waltham, USA).

\subsection{Extraction and assay of heme oxygenase}

The catalysis of the heme oxygenase $(\mathrm{HO})$ enzyme was evaluated according to the method of Balestrasse et al. (2005). Freshly harvested leaves were homogenised in a cold $\mathrm{KPO}_{4}$ buffer $(50 \mathrm{mM}, \mathrm{pH} 7.4)$ with PMSF (1 mM), EDTA (0.2 mM) and sucrose $(0.25 \mathrm{M})$. Homogenates were centrifuged for 20 minutes at $10,000 \times \mathrm{g}$ at $4^{\circ} \mathrm{C}$ and supernatants were employed for $\mathrm{HO}$ analysis. The concentration of $\mathrm{HO}$ ( $\mu \mathrm{M}$ biliverdin reduced mg ${ }^{-1}$ protein) was estimated by documenting the optical density of biliverdin (the main product of $\mathrm{HO}$ catalysis) formed by the reaction between an assay compound [KPO buffer $(50 \mathrm{mM}, \mathrm{pH} 7.4)+$ haemin $(200 \mathrm{nM})+\mathrm{NADPH}(60 \mathrm{nM})]$ and $\mathrm{HO}$ extract at $37^{\circ} \mathrm{C}$ for one hour at $650 \mathrm{~nm}$ (molar absorption coefficient $6.25 \mu \mathrm{M}^{-1} \mathrm{~cm}^{-}$ 1).

\subsection{Statistical analysis}

Statistical analysis was performed using Statistica (StatSoft, USA). Before all analyses, normal distributions were verified using the Shapiro-Wilk test. Analysis involved ANOVA and Tukey's test at the significance level of $a=0.05$ for comparisons of means in order to determine the impact of factors such as plant species, amount of accumulated PM fractions and categories, amount of waxes, amounts of Cd and Cu, and amount of heme oxygenase. Nonparametric Spearman's correlation coefficients were calculated between different measured variables. The significance of correlation was determined using $a=0.05$.

\section{Results}

\subsection{The amount of particulate matter on leaves}

The species examined in this study differed significantly in their potential to accumulate PM on their leaves. Significant differences were recorded for total PM $\left(\mathrm{PM}_{\mathrm{T}}\right)$ accumulation and different PM size fractions $(0.2-2.5,2.5-10,10-100 \mu \mathrm{m})$ and categories ( ${ }_{\mathrm{S}} \mathrm{PM}$ and $\left.{ }_{\mathrm{W}} \mathrm{PM}\right)$.

The significantly highest $\mathrm{PM}_{\mathrm{T}}$ accumulation was recorded for $F$. religiosa, $C$. myxa and $T$. cordifolia (Fig. 2). The differences in $\mathrm{PM}_{\mathrm{T}}$ between these species ranged from $117.8 \mu \mathrm{g} \mathrm{cm}^{-2}$ (F. religiosa) to $88.6 \mu \mathrm{g} \mathrm{cm}^{-2}$ (T. cordifolia), therefore F. religiosa accumulated $15 \% \mathrm{more}^{\mathrm{P} M} \mathrm{~T}_{\mathrm{T}}$ than $T$. cordifolia. Plants of $B$. spectabilis, V. nilotica, P. longifolia, C. mopane, A. indica and E. globulus ( $\mathrm{PM}_{\mathrm{T}}$ accumulation in the range of 59.4 to $\left.39.2 \mu \mathrm{cm} \mathrm{cm}^{-2}\right)$ turned out to be average $\mathrm{PM}_{\mathrm{T}}$ accumulators, while $S$. persica accumulated significantly the least $\mathrm{PM}_{\mathrm{T}}\left(17.1 \mu \mathrm{g} \mathrm{cm}^{-2}\right)$. S. persica accumulated $85 \%$ less $\mathrm{PM}$ than $F$. religiosa, which accumulated $\mathrm{PM}_{\mathrm{T}}$ most efficiently (Fig. 2).

The studied species also differed statistically in the accumulation of different PM size fractions (Table 1). On average for all species, the share of large PM was $65 \%$, coarse PM $28 \%$ and fine PM $9 \%$. The species with the highest share of large PM were C. mopane and A. indica (both about $72 \%$ ), while the lowest were $C$. myxa and $F$. religiosa (56\% and $54 \%$ respectively). F. religiosa, $C$. myxa and $V$. nilotica were characterised as having the highest share of coarse PM (35\% for $F$. religiosa and $34 \%$ for $C$. myxa and $V$. nilotica). In the case of this fraction, the lowest share was found for $C$. mopane and $A$. indica ( $20 \%$ and $16 \%$ respectively). The smallest fraction represented the highest share in the $\mathrm{PM}_{\mathrm{T}}$ accumulated by $A$. indica (13\%), B. spectabilis (13\%) and $F$. religiosa (10\%), while the lowest was recorded in S. persica (7\%), E. globulus (6\%) and T. cordifolia (6 \%) (Table 1). 
Table 1

Accumulation of different PM fractions by the leaves of 10 plant species. Data are mean $\pm S E, n=4$. Different letters indicate statistical significance for each fraction $(P<$ $0.05)$

\begin{tabular}{|c|c|c|c|c|c|c|}
\hline \multirow{3}{*}{$\begin{array}{l}\text { Species } \\
\text { Ficus religiosa }\end{array}$} & \multicolumn{6}{|c|}{$\mathrm{PM}$ size fraction $\left[\mu \mathrm{g} \mathrm{cm}^{-2}\right]$ (mean $\left.\pm \mathrm{SE}\right)$} \\
\hline & \multicolumn{2}{|c|}{$10-100[\mu \mathrm{m}]$} & \multicolumn{2}{|c|}{$2.5-10[\mu \mathrm{m}]$} & \multicolumn{2}{|c|}{$0.2-2.5[\mu \mathrm{m}]$} \\
\hline & $63.5 \pm 0.8$ & a & $42.2 \pm 0.8$ & a & $12.1 \pm 0.1$ & a \\
\hline Cordia myxa & $59.8 \pm 1.7$ & a & $36.4 \pm 1.0$ & b & $9.9 \pm 0.4$ & $a b$ \\
\hline Tinospora cordifolia & $\mathbf{5 3 . 5} \pm 1.9$ & b & $29.8 \pm 1.3$ & c & $5.3 \pm 0.3$ & c \\
\hline Bougainvillea spectabilis & $37.8 \pm 0.2$ & c & $13.6 \pm 0.6$ & de & $8.0 \pm 0.2$ & b \\
\hline Vachellia nilotica & $32.0 \pm 0.3$ & cd & $19.0 \pm 1.0$ & d & $4.4 \pm 0.1$ & cd \\
\hline Polyalthia longifolia & $32.4 \pm 1.0$ & cd & $15.4 \pm 0.6$ & de & $4.4 \pm 0.3$ & cd \\
\hline Colophospermum mopane & $35.5 \pm 0.3$ & cd & $9.7 \pm 0.3$ & ef & $3.9 \pm 0.2$ & cd \\
\hline Azadirachta indica & $31.6 \pm 0.2$ & d & $7.0 \pm 0.3$ & $f$ & $\mathbf{5 . 5} \pm 0.3$ & c \\
\hline Eucalyptus globulus & $25.0 \pm 1.1$ & e & $11.7 \pm 0.4$ & ef & $2.5 \pm 0.2$ & d \\
\hline Salvadora persica & $11.2 \pm 0.1$ & $f$ & $4.7 \pm 0.3$ & $\mathbf{g}$ & $1.2 \pm 0.0$ & e \\
\hline Average & $38.2 \pm 4.4$ & $A$ & $19.0 \pm 2.5$ & B & $\mathbf{5 . 7} \pm 1.2$ & C \\
\hline
\end{tabular}

\subsection{Amount of surface PM, in-wax PM and waxes on leaves}

The examined trees also differed statistically in terms of the amount of surface PM (sPM) and PM immobilised in waxes (wPM) (Table 2). Most of the studied species accumulated the majority of PM as SPM (an average $68 \%$ and $32 \%$ for sPM and wPM respectively). The species with the highest share of sPM were $S$. persica ( $86 \%$ of sPM in $\mathrm{PM}_{\mathrm{T}}$ ), $A$. indica ( $80 \%$ of sPM in $\mathrm{PM}_{\mathrm{T}}$ ) and $B$. spectabilis $\left(75 \%\right.$ of sPM in $\mathrm{PM}_{\mathrm{T}}$ ), while those with the lowest share were V. nilotica (56 \% of sPM in $\mathrm{PM}_{\mathrm{T}}$ ), E. globulus (57\% of sPM in $\mathrm{PM}_{\mathrm{T}}$ ) and F. religiosa (59\% of sPM in $\mathrm{PM}_{\mathrm{T}}$ ) (Table 2). Plants of E. globulus, F. religiosa and C. myxa had foliage covered with significantly the largest amount of waxes and almost three times greater than that of $P$. longifolia and $B$. spectabilis (Table 2).

Table 2

The percentage share of sPM and wPM in PMT and the amount of epicuticular waxes on the foliage of 10 plant species. Data are mean \pm SE, $n=4$. Different letters indicate statistical significance between the species $(\mathrm{P}<0.05)$.

\begin{tabular}{|c|c|c|c|c|c|c|c|c|c|c|}
\hline $\begin{array}{l}\text { Species } \\
\text { PM } \\
\text { types } \\
\text { and } \\
\text { waxes }\end{array}$ & $\begin{array}{l}\text { Ficus } \\
\text { religiosa }\end{array}$ & $\begin{array}{l}\text { Cordia } \\
\text { myxa }\end{array}$ & $\begin{array}{l}\text { Tinospora } \\
\text { cordifolia }\end{array}$ & $\begin{array}{l}\text { Bougainvillea } \\
\text { spectabilis }\end{array}$ & $\begin{array}{l}\text { Vachellia } \\
\text { nilotica }\end{array}$ & $\begin{array}{l}\text { Polyalthia } \\
\text { longifolia }\end{array}$ & $\begin{array}{l}\text { Colophospermum } \\
\text { mopane }\end{array}$ & $\begin{array}{l}\text { Azadirachta } \\
\text { indica }\end{array}$ & $\begin{array}{l}\text { Eucalyptus } \\
\text { globulus }\end{array}$ & $\begin{array}{l}\text { Salvadora } \\
\text { persica }\end{array}$ \\
\hline sPM \% & 59 & 65 & 63 & 75 & 56 & 70 & 70 & 80 & 57 & 86 \\
\hline wPM \% & 41 & 35 & 37 & 25 & 44 & 30 & 30 & 20 & 43 & 14 \\
\hline $\begin{array}{l}\text { Waxes } \\
{[\mu \mathrm{gg}} \\
\left.\mathrm{cm}^{-2}\right] \\
\text { (mean } \\
\pm \mathrm{SE} \text { ) }\end{array}$ & $\begin{array}{l}53.5 \mathrm{a} \\
\pm 2.3\end{array}$ & $\begin{array}{l}51.1 \mathrm{a} \\
\pm 4.2\end{array}$ & $\begin{array}{l}48.7 a \\
\pm 3.5\end{array}$ & $\begin{array}{l}17.3 d \\
\pm 3.4\end{array}$ & $\begin{array}{l}40.9 \mathrm{~b} \\
\pm 3.8\end{array}$ & $\begin{array}{l}17 . d \\
\pm 2.0\end{array}$ & $\begin{array}{l}30.2 c \\
\pm 0.8\end{array}$ & $\begin{array}{l}33.4 \mathrm{c} \\
\pm 2.0\end{array}$ & $\begin{array}{l}58.9 a \\
\pm 2.2\end{array}$ & $\begin{array}{l}32.9 \mathrm{c} \\
\pm 2.9\end{array}$ \\
\hline
\end{tabular}

\subsection{Amounts of $\mathrm{Cd}$ and $\mathrm{Cu}$ on/in leaves}

The examined tree and shrub species differed in their ability to accumulate heavy metals ( $\mathrm{Cd}$ and $\mathrm{Cu}$ ) in leaves (Fig. 3). B. spectabilis, F. religiosa and $P$. longifolia turned out to be the species with the highest accumulation of $\mathrm{Cu}$. These three species accumulated $35 \%$ more Cu than $E$. globulus, $A$. indica and T. cordifolia, and $65 \%$ more than C. myxa, V. nilotica and S. prersica. Statistically the highest concentrations of Cd were noted in the leaves of $C$. myxa, $F$. religiosa and V. nilotica. A very low accumulation of $\mathrm{Cd}$ was recorded in $T$. cordifolia, A. indica, E. globulus and S. prersica, while in B. spectabilis, $P$. longifolia and $C$. mopane the amount of $\mathrm{Cd}$ was below the detection level. In all species, the accumulation of Cu was considerably higher than that of $\mathrm{Cd}$ (Fig. 3).

\subsection{Activity of heme oxygenase (HO)}


The examined species differed in the activity of $\mathrm{HO}$ (Fig. 4). Significantly the highest activity of this enzyme was recorded in F. religiosa, which was twice as intense as in C. myxa and A. indica. Significantly the lowest activity of HO was noted in the leaves of S. persica, at almost $95 \%$ lower than in $F$. religiosa (Fig. 4).

\subsection{Correlations}

For all examined species, a strongly significant positive correlation was found between $\mathrm{HO}$ and all types of PM accumulated on foliage (Table 3 ). The highest correlation (0.92) was found between $\mathrm{HO}$ and the smallest PM fraction $(0.2-2.5 \mu \mathrm{m})$. A significant positive correlation was also recorded between $\mathrm{HO}$ and $\mathrm{Cu}$ concentration in leaves, while for $\mathrm{Cd}$ concentration the correlation was not significant. There were no statistically significant correlations between the amount of $\mathrm{Cu}$ in leaves and all types of PM,

Table 3

Non-parametric Spearman's correlation coefficients calculated between different categories of particulate matter (PM) and the amount of heavy metals ( $\mathrm{Cu}$ and $\mathrm{Cd}$ ) and $\mathrm{HO}$ enzyme analysed for 10 plants species. Bold values indicate a statistical significance $(P<0.05)$

\begin{tabular}{|c|c|c|c|c|c|c|c|c|}
\hline \multicolumn{7}{|c|}{ Types of PM } & \multicolumn{2}{|c|}{ Heavy metals } \\
\hline & Total & Large & Coarse & Fine & Surface $_{S} \mathrm{PM}$ & In-wax ${ }_{w} P M$ & $\mathrm{Cu}$ & $\mathrm{Cd}$ \\
\hline & $0.2-100 \mu \mathrm{m}$ & $10-100 \mu \mathrm{m}$ & $10-2.5 \mu \mathrm{m}$ & $0.2-2.5 \mu \mathrm{m}$ & & & & \\
\hline $\mathrm{HO}$ & 0.82 & 0.81 & 0.78 & 0.92 & 0.80 & 0.82 & 0.77 & 0.63 \\
\hline $\mathrm{Cu}$ & 0.44 & 0.46 & 0.40 & 0.50 & 0.41 & 0.47 & & 0.04 \\
\hline $\mathrm{Cd}$ & 0.73 & 0.67 & 0.76 & 0.79 & 0.68 & 0.76 & 0.04 & \\
\hline
\end{tabular}

\section{Discussion}

Urban vegetation plays an extremely important role in the urbanised environment (Pugh et al., 2012; Popek et al., 2017). In addition to its undeniable aesthetic values, it also fulfils important ecological functions in stabilising and shaping the climate. The presence of plants in cities can lead to reduced temperatures, higher air humidity and better water retention (Rai and Panda, 2014; Yang et al., 2005; Kroeger et al., 2018). Urban vegetation also reduces the negative impact of air pollutants (e.g. PM) on the environment and human health (Popek et al., 2017; Paton-Walsh et al., 2019). This is particularly important in areas where air pollution limits are often exceeded. An important function of this kind is usually played by trees and shrubs, which have a large, biologically active biomass to purify the air and play the role of an urban "green liver".

\subsection{Accumulation of particulate matter}

In this study, the results clearly showed that woody plants grown in the heavily polluted Indian city of Jodhpur efficiently accumulated PM on their foliage. However, the examined species differed in the amount of PM accumulated. Among the investigated species, F. religiosa accumulated the greatest amount of total PM. This tree is tall with a lush, large crown. The air turbulence between the leaves and branches of its dense crown can be an efficient trap for PM, as previously demonstrated by Xie et al. (2018). Dense but porous deciduous trees and shrubs have been shown to form street canyons that can reduce air PM concentrations by as much as 60 \% (Pugh et al. 2012). The morphology of F. religiosa leaves may also be important (Chiam et al. 2019; Muhammad et al. 2020). The leaves of this species are characterised by a wavy edge and convex veins, which can act as natural microbarriers to PM. It has been reported that PM accumulation is relatively high on the leaf margins (Mitchell et al. 2010) and/or along the main leaf nerves (Tomašević et al. 2005). In addition, the leaves of $F$. religiosa are set on long petioles, which move in the wind and actively purify the air from PM, as previously presented by Prusty et al. (2005). It is very important to note that accumulation of PM with the smallest diameter was also highest in that species, with coarse and fine PM amounting to $36 \%$ and $10 \%$ of the total PM accumulated by F. religiosa. It can be assumed that the number of particles of this fraction compared with large PM was even greater. According to Grochowicz and Korytkowski (1996), despite the low weights, the number of fine PM particles accumulated on plants can be very high. Fine and ultrafine PM fractions contribute to $30 \%$ of total PM weight, but at the same time make up $99.9 \%$ of the total number of particles (Grochowicz and Korytkowski 1996). Purifying air from fine fraction PM is most important because it represents the greatest threat to human health. Therefore, the great ability of $F$. religiosa to accumulate this fraction makes it a tree of great phytoremediation value in urban areas.

The species with the next greatest ability to accumulate PM was $C$. myxa. Like $F$. religiosa, its leaves have convex veins. They are also pubescent and when young tend to be hairy. Many morphological characteristics, such as surface roughness and the presence of trichomes, have been shown to increase the amount of PM on leaves (Leonard et al. 2016). According to Dzierżanowski and Gawroński (2011), leaves densely covered with hairs can act as aircleaning brushes.

The third and fourth species that accumulated PM most efficiently were $T$. cordifolia and $B$. spectabilis, two vigorously growing climbers. The leaf edges of these species are usually curled, which may increase PM accumulation as this leaf shape creates a 'basin' into which rainwater with associated contaminants can flow. Similar conclusions were drawn by Popek et al. (2013), who found great accumulation of PM by Syringa meyeri 'Palibin'C.K. Schneid, which has leaves with a similar morphology. Climbers are very important for city planners because these plants occupy small areas of land and, 
by climbing on the surface of buildings, can produce a huge leaf area (in relation to the land area occupied) capable of accumulating PM and other pollutants (Ottelé et al. 2010). This is especially important in cities where green areas are still limited due to a lack of space. Green walls covered with climbers can therefore be an attractive alternative to trees and shrubs. In addition, climbers are also increasingly being used to cover acoustic barriers along motorways, which are especially exposed to extremely high PM concentrations and counteract air pollution. It is noteworthy that $B$. spectabilis is another species with a very high share of the smallest PM, thus most dangerous for human health, out of total accumulated PM.

Another important species in this research turned out to be $P$. longifolia. This tree, although not characterised by very high PM accumulation, is valuable in the urban environment. It has a very dense crown and a huge mass of leaves that can filter air. This plant does not accumulate as much PM per square centimetre, but the whole tree can probably capture large amounts of PM from the air. Its narrow shape also allows this tree to be planted close to traffic routes as well as next to buildings without causing damage.

S. persica and $A$. indica were the plants that accumulated the least PM. Those two species are well known for their resistance to drought. They are commonly found in semi-arid and desert areas, and are sources of shade for other vegetation in these locations (Khatak et al. 2010). The morphology of their leaves is similar, with both having smooth and glossy leaves. Bakker et al. (1999) showed that the Plantago species with its smooth leaf surfaces accumulates less PM than densely hairy species. PM deposited on S. persica and A. indica foliage can probably easily be blown off by the wind or washed off by rain. These specific morphological features of $S$. persica and $A$. indica leaves are probably due to the places where they are found. They grow in dry and extremely dusty environments, which has probably led to the development of protective mechanisms against the deposition of particles on the leaves (not investigated in this research), otherwise PM thickly covering the leaves would impair the photosynthetic apparatus by shading the leaf blade and/or clogging the stomata (Li et al. 2019; Mina et al. 2018; Popek et al. 2018a; Siqueira-Silva et al. 2016). Moreover, both these species were characterised by a high share of coarse PM out of total accumulated PM. These results indicate that plants well adapted to drought and high air pollution are not always the most effective PM accumulators.

Low PM accumulation was also recorded for $C$. mopane and V. nilotica, invasive trees originating from Africa, and E. globulus from Australia. All three are also adapted to dry and semi-desert conditions. Low efficiency of PM accumulation in eucalyptus (unidentified species) has also been demonstrated in studies conducted on 16 tree species in Australia (Leonard et al. 2016). E. globulus and S. persica accumulated the smallest amount of the fine PM fraction, while $A$. indica was the species with a large share of this fraction out of the total mass of PM deposited on foliage.

\subsection{Relationship between the amount of epicuticular waxes and PM accumulation}

Opinions vary about whether the amount of waxes on foliage increases PM accumulation (Jouraeva et al. 2002; Popek et al. 2015; Renault et al. 2017; Sæb $\varnothing$ et al. 2012). The undeniable fact, however, is that part of the PM is immobilised on and in the wax layer. In-wax particles ( $\left.{ }^{P} P M\right)$, unlike those deposited directly on the leaf surface $\left.{ }_{S} \mathrm{PM}\right)$, are strongly attached to the leaf surface and it is not easy for them to be washed away by rain or blown by the wind; they also can be removed from the environment with falling leaves (Jouraeva et al. 2002; Sæbø et al. 2012). In this study, the species with the highest PM accumulation (F. religiosa, C. myxa, T. cordifolia) were also the ones that produced very high amounts of waxes on their leaves. Moreover, the share of PM immobilised in waxes was also highest (about $40 \%$ ) in these species. Similar results have been obtained for silver birch (Betula pendula L.) and Scots pine (Pinus sylvestris L.) on whose foliage a large amount of wax on leaves causes a high accumulation of ${ }_{w} P M(P o p e k$ et al. 2015; Sæbø et al. 2012). In contrast, a species with the highest amounts of waxes recorded in this work (E. globulus) was not efficient at PM accumulation. Similar results have been presented by Popek et al. (2019), who show that two Australian tree species, Sweet Pittosporum (Pittosporum undulatum Vent.) and Large Mock-olive (Notelaea longifolia Vent.), accumulate only slightly less PM than swamp gum (Eucalyptus ovata Labill.) despite a much thinner wax layer. As many researchers have noted, these contrasting data suggest that not only the total wax content, but also its chemical composition or structure, may be important for efficient PM accumulation (Jouraeva et al. 2002; Łukowski et al. 2018; Popek et al. 2015; Przybysz et al. 2014; Sæbø et al. 2012). In this work, taking into account all the species together, the amount of wax was positively correlated with the amount of ${ }_{W} P M(r=0.66$; $P<0.0001)$. This has also been noted in the studies of Sæbø et al. (2012) and Przybysz et al. (2014), but not those of Łukowski et al. (2018) or Popek et al. (2019). It should be noted that some types of PM may affect negatively the structure and degradation of waxes, thus affecting the amount of PM accumulated (Jouraeva et al. 2002).

\subsection{HM concentration in leaves}

The concentrations of HMs on/in leaves can be significantly affected by PM concentration in the air (Liu et al. 2019; Maisto et al., 2004; Przybysz et al. 2019; Shahid et al. 2017). Approximately 70 \% of the As, Pb, Zn, and Cd mass is emitted to the air as PM (Bartnicki 1994). In this study, Cu and Cd were found in the leaves of almost every examined species. Probably due to the long distance from roads (or other sources of HMs), the concentrations of both HMs were low, approximately five times lower than in the research of Popek et al. (2017) on small-leaved lime trees (Tilia cordata L.) growing close to roads in cities with high PM pollution. Furthermore, Mori et al. (2015), Noh et al. (2019) and Zhu et al. (2019) show that the PM concentration in leaves increases with decreasing distance from the emission source. In this study, it was impossible to estimate how much of the HMs was taken up from the soil and how much was of atmospheric origin. According to Maisto et al. (2004), Cd and Cu are most often accumulated in ionic form from the soil and then translocated from the roots to the leaves; direct accumulation from the atmosphere is less likely. However, Przybysz et al. (2019) demonstrate that concentrations of $\mathrm{Ni}, \mathrm{Pb}, \mathrm{Cd}$ and $\mathrm{Sb}$ are higher in $\mathrm{PM}$ accumulated on foliage than in plant tissue, offering clear evidence that airborne PM could be an important source of HMs and that plants, if used properly, can serve as efficient green filters purifying ambient air from toxic HMs. In this study, concentrations of $\mathrm{Cu}$ in leaves were not correlated with accumulated PM, while concentrations of Cd were significantly correlated with fine and coarse PM deposited on foliage. These results are in agreement with Bartnicki (1994), who found that HMs on leaves are associated with PM of a diameter less than $0.95 \mathrm{~mm}$, which in urban areas is mainly of anthropogenic origin. Sörme et al. (2001) and Hjortenkrans et al. (2006) demonstrate that increased amounts of $\mathrm{Cd}$ in PM usually have their origins in traffic emissions, especially in association with abraded vehicle tires. The results of the present study also showed 
a positive correlation between $\mathrm{Cd}$ and ${ }_{\mathrm{W}} \mathrm{PM}$. In contrast to the above, according to Przybysz et al. (2019) HMs are recorded in all PM size fractions accumulated by plants and are fairly equally distributed between surface PM (sPM) and in-wax PM (wPM).

\subsection{Heme oxygenase as the response to the PM stress}

Heme oxygenase (HO) is an enzyme involved in plant responses to various abiotic stresses, including heavy metals (Hancock and Russell 2021; He and He 2014; Mahawar et al. 2021; Shekhawat and Verma,2010; Shekhawat et al. 2011; Shekhawat et al. 2019). In this study, a positive correlation was recorded between $\mathrm{HO}$ and concentrations of both $\mathrm{HMs}$ (Cu and Cd) in and on leaves, but only significantly so in the case of Cu. Mahawar and Shekhawat (2018) show that the activity of $\mathrm{HO}$ increases with an increasing concentration of $\mathrm{Cd}$ in plants and time of exposure to this metal. The participation of $\mathrm{HO}$ in defensive responses against $\mathrm{Cd}$ has also been demonstrated by Balestrasse et al. (2008) and Noriega et al. (2012). Mahawar and Shekhawat (2018), Noriega et al. (2012), Hancock and Russell (2021) and Mahawar et al. (2021) suggest that HO may be involved in mitigating the effects of stress caused by most heavy metals. The new finding in the present study was that the activity of HO was significantly positively correlated with PM (all examined fractions and categories) accumulated on plant foliage. Moreover, the correlation between $\mathrm{HO}$ and PM was stronger than between $\mathrm{HO}$ and $\mathrm{HMs}$. PM has a wellknown negative effect on plants, especially on the photosynthetic apparatus (Li et al. 2019; Mina et al. 2018; Mudway et al. 2020; Piacentini et al. 2019; Popek et al. 2018a; Singh et al. 2019; Zhou et al. 2018). The high activity of HO in the leaves of plants growing in conditions of increased PM concentration in the air may indicate that the defence reactions of plants to PM are more complicated than previously thought, and that plants accumulating large amounts of PM must adapt to their unfavourable impact. $\mathrm{HO}$ is produced and active mainly in leaves and may be involved in alleviating the oxidative stress (Mahawar and Shekhawat 2018) induced in plants by PM (Mudway et al. 2020; Piacentini et al. 2019). Li et al. (2014), Mahawar and Shekhawat (2018), Verma et al. (2013) and Zhu et al. (2017) show that HO is related to chlorophyll biosynthesis, which may be important in plants suffering from a dysfunctional photosynthetic apparatus due to the negative effects of PM.

\section{Conclusions}

Urban residents struggle with high air pollution, especially PM, in their cities every day. The results of this study showed that woody plants can actively biofiltrate PM and HMs from the air in a heavily polluted Indian city. The phytoremediation properties of plants should be taken into account in the planning, selection, planting and maintenance of urban greenery. Some species, such as F. religiosa, accumulated PM more efficiently, while others, such as the semi-desert species $A$. indica and S. persica, avoided high PM deposition on foliage, which is probably due to their adaptation to growing conditions. PM accumulation by plants depends on various factors, such as the density and porosity of the crown, the shape and morphology of the leaf, and the presence of hairs and epicuticular waxes on foliage. The accumulation of HMs (especially $\mathrm{Cu}$ ) was positively correlated with the amount of PM deposited on the leaves. A new finding of this study indicated a potentially important role of HO in the plants' response to PM-induced stress. The correlation between $\mathrm{HO}$ and $\mathrm{PM}$ was stronger than that between $\mathrm{HO}$ and $\mathrm{HMs}$. The results obtained in this study emphasise the role of plants in cleaning polluted air in conditions where there are very high concentrations of PM, and shed new light on the defence responses of plants against PM.

\section{Declarations}

Availability of data and materials: The data and materials from the current study are available from the corresponding author on reasonable request.

Author contribution: Robert Popek: Conceptualization, Methodology, Validation, Formal analysis, Investigation, Resources, Writing - original draft, Writing review \& editing, Visualization, Supervision, Funding acquisition. Lovely Mahawar: Investigation, Validation, Writing - review \& editing, Visualization. Gyan Singh Shekhawat: Validation, Formal analysis, Resources, Writing - review \& editing, Supervision. Arkadiusz Przybysz: Formal analysis, Writing - review \& editing, Visualization, Supervision.

Funding: This study was supported by TECO (Technological Eco-Innovations for the Quality Control of Polluted Waters and Soils), funded by the European Union, and by the University Grant Commission, New Delhi through the Centre for Advanced Studies (CAS) Programme.

Ethics approval and consent to participate: Not applicable.

Consent for publication: Not applicable.

Acknowledgements: Not applicable.

Competing interests: The authors declare no competing interests.

\section{References}

1. Alghamdi MA (2016) Characteristics and risk assessment of heavy metals in airborn $\mathrm{PM}_{10}$ from a residential area of northern Jeddah City, Saudi Arabia. Polish J Environ Stud 25:939-949. https://doi.org/10.15244/pjoes/61531.

2. Bakker MI, Vorenhout M, Sijm DTHM, Kolloeffel C (1999) Dry deposition of atmospheric polycyclic aromatic hydrocarbons in three Plantago species. Environ Toxicol Chem 18:2289-2294. https://doi.org/10.1002/etc.5620181025.

3. Balestrasse KB, Noriega GO, Batlle A, Tomaro ML (2005) Involvement of heme oxygenase as antioxidant defense in soybean nodules. Free Radic Res 39(2):145-51. https://doi.org/10.1080/10715760400022319. 
4. Balestrasse KB, Yannarelli GG, Noriega GO, Batlle A, Tomaro ML (2008) Heme oxygenase and catalase gene expression in nodules and roots of soybean plants subjected to cadmium stress. Biometals 21:433-441. https://doi.org/10.1007/s10534-008-9132-0.

5. Bartnicki J (1994). An eulerian model for atmospheric transport of heavy metals over Europe: model description and preliminary testing. Water Air Soil Pollut 75:227-263. https://doi.org/10.1007/BF00482939.

6. Chernysheva VV, Zakharenkoa AM, Ugaya SM, Hiena TT, Haia LH, Kholodova AS, Burykinae TI, Stratidakisb AK, Mezhuevc YaO, Tsatsakisa AM, Golokhvasta KS (2018) Morphologic and chemical composition of particulate matter inmotorcycle engine exhaust. Toxicol Rep 5:224-230. https://doi.org/10.1016/j.toxrep.2018.01.003.

7. Chiam Z, Song XP, Ran LH, Tan HTW (2019) Particulate matter mitigation via plants: understanding complex relationships with leaf traits. Sci Total Environ 688:98-408. https://doi.org/10.1016/j.scitotenv.2019.06.263.

8. Dzierżanowski K, Gawroński SW (2011). Use of trees for reducing particulate matter pollution in air. Challenges of Modern Technology 1:69-73.

9. Dzierżanowski K, Popek R, Gawrońska H, Sæbø A, Gawroński SW (2011) Deposition of particulate matter of different size fractions on leaf surfaces and in waxes of urban forest species. Int J Phytoremediation 13:1037-1046. https://doi.org/10.1080/15226514.2011.552929.

10. Fang P, Sun T, Wang Y, Ding Y, Pandey AK, Zhu C, Xu P (2021) Plant gasotransmitters: light molecules interplaying with heavy metals. Rev Environ Sci Biotechnol 20:31-53. https://doi.org/10.1007/s11157-020-09562-w.

11. Ghasemi FF, Dobaradaran S, Saeedi R, Nabipour I, Nazmara S, Abadi DR, Arfaeinia H, Ramavandi B, Spitz J, Mohammadi MJ, Keshtkar M (2020) Levels and ecological and health risk assessment of PM 2.5-bound heavy metals in the northern part of the Persian Gulf. Environ Sci Pollut Res 27:5305-5313. https://doi.org/10.1007/s11356-019-07272-7.

12. Ghorbanli M, Bakand Z, Bakhshi khaniki G, Bakand S (2007) Air pollution effects on the activity of antioxidant enzymes in Nerium oleander and Robinia pseudo acacia plants in Tehran. Iranian Journal of Environmental Health Science \& Engineering 4(3):157-162.

13. Gobbi GP, Barnaba F, Giorgi R, Santacasa A (2000) Altitude resolved properties of a Saharan dust event over the Mediterranean. Atmos Environ 34(2930):5119-5127. https://doi.org/10.1016/S1352-2310(00)00194-1.

14. Gostin IN (2009) Air pollution effects on the leaf structure of some Fabaceae species. Not Bot Horti Agrobot Cluj-Napoca 37:57-63. DOI: https://doi.org/10.15835/nbha3723078.

15. Greenstone M, Fan C (2020) Air quality life index, Annual Update; Energy Policy Institute at the University of Chicago: Chicago (IL) USA, 2020.

16. Grochowicz E, Korytkowski J (1996) Air protection. Polish Educational Publisher [Ochrona Powietrza. Wydawnictwo Szkolne i Pedagogiczne.] 2:17.

17. Han D, Shen H, Duan W, Chen L (2020) A review on particulate matter removal capacity by urban forests at different scales. Urban For Urban Green 48:126565. https://doi.org/10.1016/j.ufug.2019126565.

18. Hancock JT, Russell G (2021) Downstream Signaling from Molecular Hydrogen Plants (Basel) 10(2):367. https://doi.org/10.3390/plants10020367.

19. Haynes A, Popek R, Boles M, Paton-Walsh C, Robinson SA (2019) Roadside moss turfs in South East Australia capture more particulate matter along an urban gradient than a common native tree species. Atmosphere 10:224. https://doi.org/10.3390/atmos10040224.

20. He H, He L (2014) Heme oxygenase 1 and abiotic stresses in plants. Acta Physiol. Plant. 36:581-588. https://doi.org/10.1007/s11738-013-1444-1.

21. Hjortenkrans D, Bergbäck B, Häggerud A (2006) New metal emission patterns in road traffıc environments. Environ Monit Assess 117:85-98. https://doi.org/:10.1007/s10661-006-7706-2.

22. Hsu HH, Chiu YH, Coull BA, Kloog I, Schwartz J, Lee A, Wright RO, Wright RJ (2015) Prenatal particulate air pollution and asthma onset in urban children. Identifying sensitive windows and sex differences. Am J of Respir Crit Care Med 192:1052-1059. https://doi.org/doi:10.1164/rccm.20150406580C.

23. Jędrychowski WA, Perera FP, Camann D, Spengler J, Butscher M, Mroz E, Majewska R, Flak E, Jacek R, Sowa A (2015) Prenatal exposure to polycyclic aromatic hydrocarbons and cognitive dysfunction in children. Environ Sci Pollut Res. 22:3631-3639. https://doi.org /doi:10.1007/s11356-014-3627-8.

24. Jin EJ, Yoon JH, Bae EJ, Jeong BR, Yong SH, Choi MS (2021) Particulate matter removal ability of ten evergreen trees planted in Korea urban greening. Forests 12:438. https://doi.org/10.3390/f12040438.

25. Jouraeva VA, Johnson DL, Hassett JP, Nowak DJ (2002) Differences in accumulation of PAHs and metals on the leaves of Tilia xeuchlora and Pyrus calleryana. Environ Pollut 120:331-338. https://doi.org/10.1016/S0269-7491(02)00121-5.

26. Khatak M, Khatak S, Siddqui AA, Vasudeva N, Aggarwal A, Aggarwal P (2010) Salvadora persica. Pharmacogn Rev 4(8):209214. https://doi.org/10.4103/0973-7847.70920.

27. Kim K-H, Kabir E, Kabir S (2015) A review on the human health impact of airborne particulate matter. Environ Int 74:136-143. https://doi.org /10.1016/j.envint.2014.10.005.

28. Kiyomizu T, Yamagishi S, Kume A, Hanba AT (2019) Contrasting photosynthetic responses to ambient air pollution between the urban shrub Rhododendron × pulchrum and urban tall tree Ginkgo biloba in Kyoto city: stomatal and leaf mesophyll morpho-anatomies are key traits. Trees 33:6377. https://doi.org/10.1007/s00468-018-1759-z.

29. Kroeger T, McDonald RI, Boucher T, Zhang P, Wang L (2018) Where the people are: current trends and future potential targeted investments in urban trees for PM10 and temperature mitigation in 27 U.S. cities. Landsc Urban Plan 177:227-240. https://doi.org/10.1016/j.landurbplan.2018.05.014.

30. Lawal A, Zhang M, Dittmar M, Lulla A, Araujo JA (2015) Heme oxygenase-1 protects endothelial cells from the toxicity of air pollutant chemicals. Toxicol Appl Pharmacol 284(3):281-291. https://doi.org/10.1016/j.taap.2015.01.010. 
31. Lecube ML, Noriega GO, Santa Cruz DM, Tomaro ML, Batlle A, Balestrasse KB (2014) Indole acetic acid is responsible for protection against oxidative stress caused by drought in soybean plants: The role of heme oxygenase induction. Redox Report 19(6):242-250.

https://doi.org/10.1179/1351000214Y.0000000095.

32. Leonard RJ, McArthur C, Hochuli DF (2016) Particulate matter deposition on roadside plants and the importance of leaf trait combinations. Urban For Urban Green 20:249-25. https://doi.org/10.1016/j.ufug.2016.09.008.

33. Li Q, Zhu F, Gao X, Sun Y, Li S, Tao Y, Lo C, Liu H (2014) Young leaf chlorosis 2 encodes the stroma-localized heme oxygenase 2 which is required for normal tetrapyrrole biosynthesis in rice. Planta 240:701-712.

34. Li XP, Fan SX, Guan JH, Zhao F, Dong L (2019) Diversity and influencing factors on spontaneous plant distribution in Beijing Olympic Forest Park. Landsc Urban Plan 181:157-168. https://doi.org/10.1016/j.landurbplan.2018.09.018.

35. Lin J, Pan D, Davis SJ, Zhang Q, He K, Wang C, Streets DG, Wuebbles DJ, Guan D (2014) China's international trade and air pollution in the United States. Proc Natl Acad Sci USA 111:1736-1741. https://doi.org/10.1073/pnas.1312860111.

36. Liu HL, Zhou J, Li M, Hu Y, Liu X, Zhou J (2019) Study of the bioavailability of heavy metals from atmospheric deposition on the soil-pakchoi (Brassica chinensis L.) system. Journal of Hazardous Materials 362:9-16. https://doi.org 10.1016/j.jhazmat.2018.09.032.

37. Luo Y, Hu H, Zhao M, Li H, Liu S, Fang J (2019) Latitudinal pattern and the driving factors of leaf functional traits in 185 shrub species across eastem China. J Plant Ecol 12:67-77. https://doi.org/ 10.1093/jpe/rtx065.

38. Łukowski A, Popek R, Jagiełło R, Mąderek E, Karolewski P (2018) Particulate matter on two Prunus spp. decreases survival and performance of the folivorous beetle Gonioctena quinquepunctata. Environ Sci Pollut Res 25:16629-16639. https://doi.org/10.1007/s11356-018-1842-4.

39. Łukowski A, Popek R, Karolewski P (2020) Particulate matter on foliage of Betula pendula, Quercus robur, and Tilia cordata: Deposition and ecophysiology. Environ Sc. Pollut Res 27:10296-1030. https://doi.org/10.1007/s11356-020-07672-0.

40. Mahawar L, Kumar R, Shekhawat GS (2018) Evaluation of heme oxygenase 1 (HO 1) in Cd and Ni induced cytotoxicity and crosstalk with ROS quenching enzymes in two to four leaf stage seedlings of Vigna radiata . Protoplasma 255:527-545. https://doi.org/10.1007/s00709-017-1166-0.

41. Mahawar L, Popek R, Shekhawat GS, Alyemeni MN, Ahmad P (2021) Exogenous hemin improves $\mathrm{Cd}^{2+}$ tolerance and remediation potential in Vigna radiata by intensifying the HO-1 mediated antioxidant defence system. Scientific Reports 11:2811. https://doi.org/10.1038/s41598-021-82391-1.

42. Mahawar L, Shekhawat GS (2018) Haem oxygenase: a functionally diverse enzyme of photosynthetic organisms and its role in Phytochrome chromophore biosynthesis, cellular signalling and defence mechanisms. Plant Cell Environ 41:483-500. https://doi.org /10.1111/pce.13116.

43. Maisto G, Alfani A, Baldantoni D, De Marco A, Virzo De Santo A (2004) Trace metals in the soil and in Quercus ilex L. leaves at anthropic and remote sites of the Campania Region of Italy. Geoderma 122(2-4):269-79. https://doi.org /10.1016/j.geoderma.2004.01.013.

44. Mina U, Chandrashekara TK, Kumar SN, Meena MC, Yadav S, Tiwari S, Singh D, Kumar P, Kumar R (2018). Impact of particulate matter on basmati rice varieties grown in Indo-Gangetic Plains of India: Growth, biochemical, physiological and yield attributes. Atmos Environ 188:174-184. https://doi.org /10.1016/j.atmosenv.2018.06.015.

45. Mitchell R, Maher BA, Kinnersley R (2010) Rates of particulate pollution deposition onto leaf surfaces: temporal and inter-species magnetic analyses. Environ Pollut 158:1472-1478. https://doi.org /10.1016/j.envpol.2009.12.029.

46. Mori J, Hanslin HM, Burchi G, Sæbø A (2015) Particulate matter and element accumulation on coniferous trees at different distance from a highway. Urban For Urban Green 14:170-177. https://doi.org/10.1016/j.ufug.2014.09.005.

47. Mudway IS, Kelly FJ, Holgate ST (2020) Oxidative stress in air pollution research. Free Radic Biol Med 151:2-6. .doi: 10.1016/j.freeradbiomed.2020.04.031

48. Muhammad S, Wuyts K, Samson R (2020) Immobilized atmospheric particulate matter on leaves of 96 urban plant species. Environ Sci Pollut Res 27:36920-36938. https://doi.org/ 10.1007/s11356-020-09246-6.

49. Ndour M, Conchon P, D'Anna B, Ka O, George C (2009) Photochemistry of mineral dust surface as a potential atmospheric renoxification process. Geophys Res Lett 36:L05816. https://doi.org /10.1029/2008GL036662.

50. Noh K, Thi LT, Jeong BR (2019) Particulate matter in the cultivation area may contaminate leafy vegetables with heavy metals above safe levels in Korea. Environ Sci Pollut Res Int 26(25):25762-25774. https://doi.org/10.1007/s11356-019-05825-4.

51. Noriega G, Cruz DS, Batlle A, Tomaro M, Balestrasse K (2012) Heme Oxygenase is involved in the protection exerted by jasmonic acid against cadmium stress in soybean roots. J Plant Growth Regul 31:79-89. https://doi.org/10.1007/s00344-011-9221-0.

52. OECD (Organization For Economic Co-Operation And Development) (2012) Environmental Outlook to 2050. The Consequences of Inaction. OECD Publishing, Paris, France.

53. Ottelé M, van Bohemen HD, Fraaij ALA (2010) Quantifying the deposition of particulate matter on climber vegetation on living walls. Ecol Eng 36(2):154-62.

54. Paton-Walsh C, Rayner P, Simmons J, Fiddes SL, Schofield R, Bridgman H, Beaupark S, Broome R, Chambers SD, Tzu-Chi Chang L, Cope M, Cowie C, Desservettaz M, Dominick D, Emmerson K, Forehead H, Galbally IE, Griffiths A, Guérette E-A, Haynes A, Heyworth J, Jalaludin B, Kan R, Keywood M, Monk K, Morgan G, Nguyen Duc H, Phillips F, Popek R, Scorgie Y, Silver JD, Utembe S, Wadlow I, Wilson SR, Zhang Y (2019) A clean air plan for Sydney: An overview of the special issue on air quality in New South Wales. Atmosphere 10:774. https://doi.org /10.3390/atmos10120774.

55. Piacentini D, Falasca G, Canepari S, Massimi L (2019) Potential of PM-selected components to induce oxidative stress and root system alteration in a plant model organism. Environ Int 132:105094. https://doi.org/10.1016/j.envint.2019.105094. 
56. Popek R, Gawrońska H, Sæbø A, Wrochna M, Gawroński SW (2013) Particulate matter on foliage of 13 woody species: Deposition on surfaces and phytostabilisation in waxes-a 3 year study. Int J Phytoremediation 15(3):245-256. https://doi.org /10.1080/15226514.2012.694498.

57. Popek R, Gawrońska H, Gawroński SW (2015) The level of particulate matter on foliage depends on the distance from the source of emission. Int J Phytoremediation 17:1262-1268. https://doi.org/ 10.1080/15226514.2014.989312.

58. Popek R, Łukowski A, Bates C, Oleksyn J (2017) Particulate matter, heavy metals and polycyclic aromatic hydrocarbons accumulation on the leaves of Tilia cordata Mill. in five Polish cities with different level of air pollution. Int J Phytoremediation 19(12):1134-1141. https://doi.org/10.1080/15226514.2017.1328394.

59. Popek R, Łukowski A, Grabowski M (2018a) Influence of particulate matter accumulation on photosynthetic apparatus of Physocarpus opulifolius and Sorbaria sorbifolia. Pol J Environ Stud 27(5):2391-2396. https://doi.org/10.15244/pjoes/78626.

60. Popek R, Przybysz A, Gawrońska H, Klamkowski K, Gawroński SW (2018b) Impact of particulate matter accumulation on the photosynthetic apparatus of roadside woody plants. Ecotoxicol Environ Saf 163:56-62. https://doi.org/10.1016/j.ecoenv.2018.07.051.

61. Popek R, Haynes A, Przybysz A, Robinson SA (2019) How much does weather matter? Effects of rain and wind on PM accumulation by four species of Australian native trees. Atmosphere 10:633. https://doi.org/10.3390/atmos10100633.

62. Prusty BAK, Mishra PC, Azeez PA (2005) Dust accumulation and leaf pigment content in vegetation near the national highway at Sambalpur, Orissa, India. Ecotoxicol Environ Saf 60:228-235. https://doi.org/10.1016/j.ecoenv.2003.12.013.

63. Przybysz A, Popek R, Gawrońska H, Grab K, Romanowska K, Wrochna M, Gawroński SW (2014) Efficiency of photosynthetic apparatus of plants grown in sites differing in level of PM. Acta Scientiarum Polonorum Hortorum Cultus (13):216-222.

64. Przybysz A, Nersisyan G, Gawroński SW (2019) Removal of particulate matter and trace elements from ambient air by urban greenery in the winter season. Environ Sci Pollut Res 26:473-482. https://doi.org/10.1007/s11356-018-3628-0.

65. Pugh TAM, MacKenzie AR, Whyatt JD, Hewitt CN (2012) Effectiveness of green infrastructure for improvement of air quality in urban street canyons. Environ Sci Technol 46:7692-7699. https://doi.org/10.1021/es300826w.

66. Rai PK, Panda LS (2014) Dust capturing potential and air pollution tolerance index (APTI) of some road side tree vegetation in Aizawl, Mizoram, India: an Indo-Burma hot spot region. Air Qual. Atmos Health 7(1):193-101. https://doi.org /10.1007/s11869-013-0217-8.

67. Renault H, Alber A, Horst NA, Basilio Lopes A, Rich EA, Kriegshauser L, Wiedemann G, Ullmann P, Herrgott L, Erhardt M, Pineau E, Ehlting J, Schmitt M, Rose JKC, Reski R, Werck-Reichhart D (2017) A phenol-enriched cuticle is ancestral to lignin evolution in plants. Nat Commun 8:14713. https://doi.org/10.1038/ncomms14713.

68. Saravia J, Lee G/I, Lomnicki S, Dellinger B, Cormier SA (2013) Particulate matter containing environmentally persistent free radicals and adverse infant respiratory health effects: a review. J Biochem Mol Toxicol 27:56-68. https://doi.org /10.1002/jbt.21465.

69. Sarkar S, Chauhan A, Kumar R, Singh RP (2019) Impact of deadly dust storms (May 2018) on air quality, meteorological, and atmospheric parameters over the northern parts of India. GeoHealth 3:67-80. https://doi.org/10.1029/2018GH000170.

70. Sæb $\varnothing$ A, Popek R, Nawrot B, Hanslin HM, Gawronska H, Gawronski SW (2012) Plant species differences in particulate matter accumulation on leaf surfaces. Sci Total Environ 427-428:347-354. https://doi.org/10.1016/j.scitotenv.2012.03.084.

71. Shahid M, Dumat C, Khalid S, Schreck E, Xiong T, Khan NN (2017) Foliar heavy metal uptake, toxicity and detoxification in plants: a comparison of foliar and root metal uptake. J Hazard Mater 325:36-58. https://doi.org/10.1016/j.jhazmat.2016.11.063.

72. Sharma P, Yadav P, Ghosha C, Singh B (2020) Heavy metal capture from the suspended particulate matter by Morus alba and evidence of foliar uptake and translocation of PM associated zinc using radiotracer (65Zn). Chemosphere 254:126863. https://doi.org/10.1016/j.chemosphere.2020.126863.

73. Shekhawat GS., Dixit S., Verma K., Nasybullina E.I., Kosmachevskaya O.V., Topunov A.F. 2011. Heme oxygenase: enzyme with functional diversity. J. Stress Physiol. Biochem. 7: 88-94.

74. Shekhawat GS, Parihar S, Mahawar L, Khator K, Bulchandani N (2019) Bilin metabolism in plants: Structure, function and Hemeoxygenase regulation of Bilin biosynthesis. Encyclopedia of Life Sciences. https://doi.org/10.1002/9780470015902.a0028352.

75. Shekhawat GS, Verma K (2010) Heme oxygenase [HO]: an overlooked enzyme of plant metabolism and defence. J Exp Bot 61:2255-2270. https://doi.org/10.1093/jxb/erq074.

76. Singh SK, Singh RK, Singh RS, Pal D, Singh KK, Singh PK (2019) Screening potential plant species for arresting particulates in Jharia coalfield, India. Sustain Environ Res 29:37. https://doi.org/10.1186/s42834-019-0039-y.

77. Siqueira-Silva Al, Pereira EG, Modolo LV, Lemos-Filho JP, Paiva EA (2016) Impact of cement dust pollution on Cedrela fissilis Vell. (Meliaceae): a potential bioindicator species. Chemosphere 158:56-65. https://doi.org/10.1016/j.chemosphere.2016.05.047.

78. Sörme L, Bergbäck B, Lohm U (2001) Goods in the atmosphere as a metal emission source. Water Air Soil Pollut Focus 1:213-227. https://doi.org /10.1023/A:1017516523915.

79. Tomašević M, Vukmirović Z, Rajšić S, Tasić M, Stevanović B (2005). Characterization of trace metal particles deposited on some deciduous tree leaves in an urban area. Chemosphere 61:753-760. https://doi.org /10.1016/j.chemosphere.2005.03.077.

80. Uzu G, Sobanska S, Sarret G, Munoz M, Dumat C (2010) Foliar lead uptake by lettuce exposed to atmospheric fallouts. Environ Sci Technol 44(3):10361042. https://doi.org/ 10.1021/es902190u.

81. Vailshery LS, Jaganmohan M, Nagendra H (2013) Effect of street trees on microclimate and air pollution in a tropical city. Urban For Urban Green 12:408-415. https://doi.org /10.1016/j.ufug.2013.03.002. 
82. Verma K, Mehta SK, Shekhawat GS (2013) Nitric oxide [NO] counteracts cadmium induced cytotoxic processes mediated by reactive oxygen species [ROS] in Brassica juncea: cross-talk between ROS, NO and antioxidant responses. Biometals 26 255-269. https://doi.org/10.1007/s10534-013-9608-4.

83. Wegiel B, Nemeth Z, Correa-Costa M, Bulmer AC, Otterbein LE (2014) Antioxidants \& Redox Signaling 20:1709-1722. http://doi.org/10.1089/ars.2013.5667.

84. Wei X, Lyu S, Yu Y, Wang Z, Liu H, Pan D, Chen J (2017) Phylloremediation of Air Pollutants: Exploiting the Potential of Plant Leaves and LeafAssociated Microbes. Front Plant Sci 8:1318. https://doi.org/10.3389/fpls.2017.01318.

85. Weuve J, Puett RC, Schwartz J, Yanosky JD, Laden F, Grodstein F (2012) Exposure to particulate air pollution and cognitive decline in older women. Archives of Internal Medicine 172:219-227. https://doi.org /10.1001/archinternmed.2011.683.

86. Wilks A (2002) Heme oxygenase: evolution, structure, and mechanism. Antioxid Redox Signal 4:603-14.

87. World Health Organization. World Health Statistics Monitoring health for the SDGs; WHO Press: Geneva, Switzerland, 2017.

88. World Health Organization. World health statistics monitoring health for the SDGs, sustainable development goals. WHO Press: Geneva, Switzerland, 2020.

89. Yang J, McBride J, Zhou J, Sun Z (2005) The urban forest in Beijing and its role in air pollution reduction. Urban For Urban Green 3:6578. https://doi.org/10.1016/j.ufug.2004.09.001.

90. Zhou L, Chen X, Tian X (2018) The impact of fine particulate matter (PM2.5) on China's agricultural production from 2001 to 2010 . Journal of Cleaner Production 178:133-141, https://doi.org/10.1016/j.jclepro.2017.12.204.

91. Zhu L, Yang Z, Zeng X, Gao J, Liu J, Yi B, Ma C, Shen J, Tu J, Fu T, Wen J (2017) Heme oxygenase 1 defects lead to reduced chlorophyll in Brassica napus. Plant Mol Biol 93:579-592. https://doi.org/10.1007/s11103-017-0583-y

92. Zhu Z, Huang Y, Wu X, Liu Z, Zou J, Chen Y, Su N, Cui J (2019) Increased antioxidative activity and decreased cadmium uptake contribute to hemininduced alleviation of cadmium toxicity in Chinese cabbage seedlings. Ecotoxicol Environ Saf 177:47-57. https://doi.org /10.1016/j.ecoenv.2019.03.113.

\section{Figures}

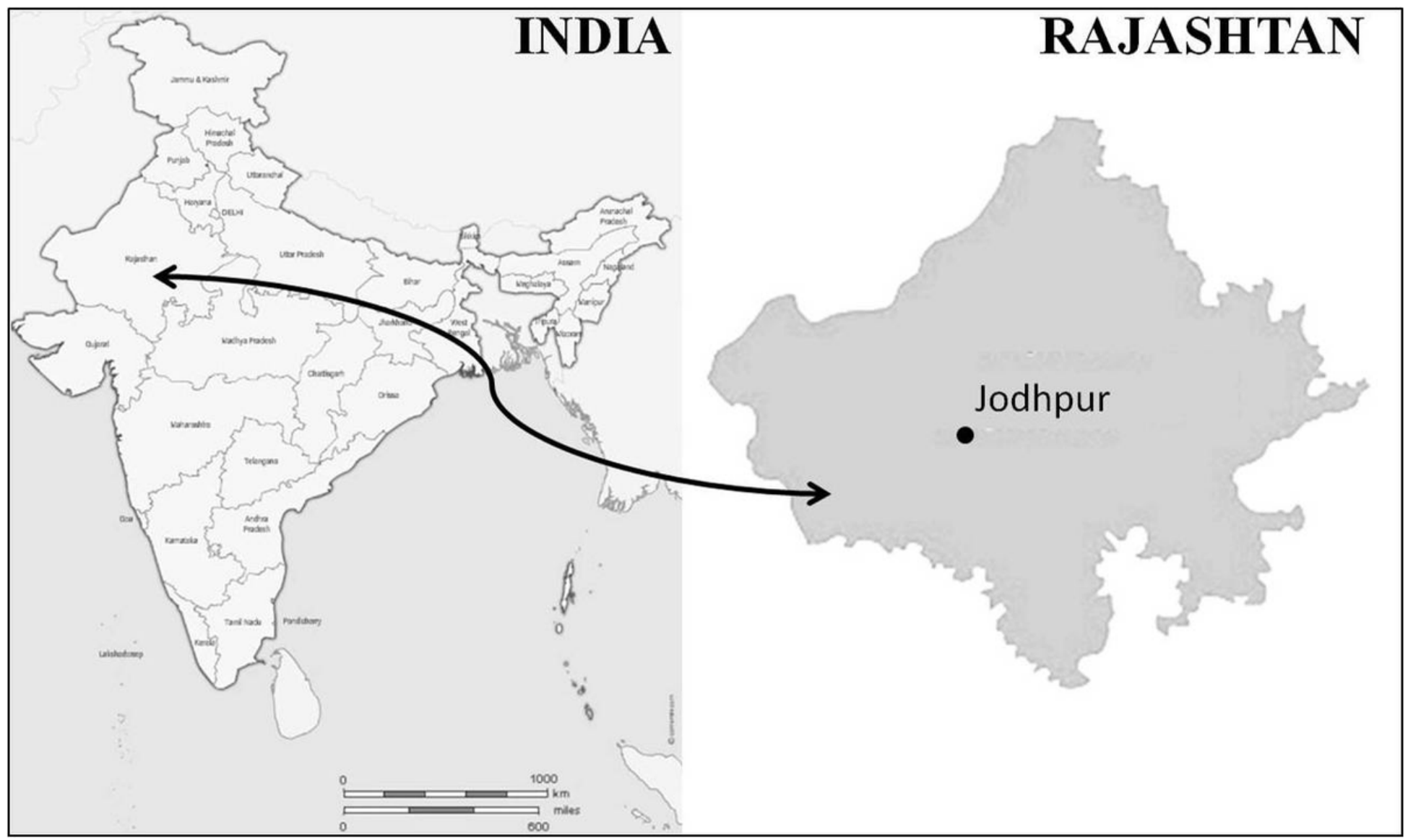

Figure 1

Map showing the location of the city of Jodhpur 


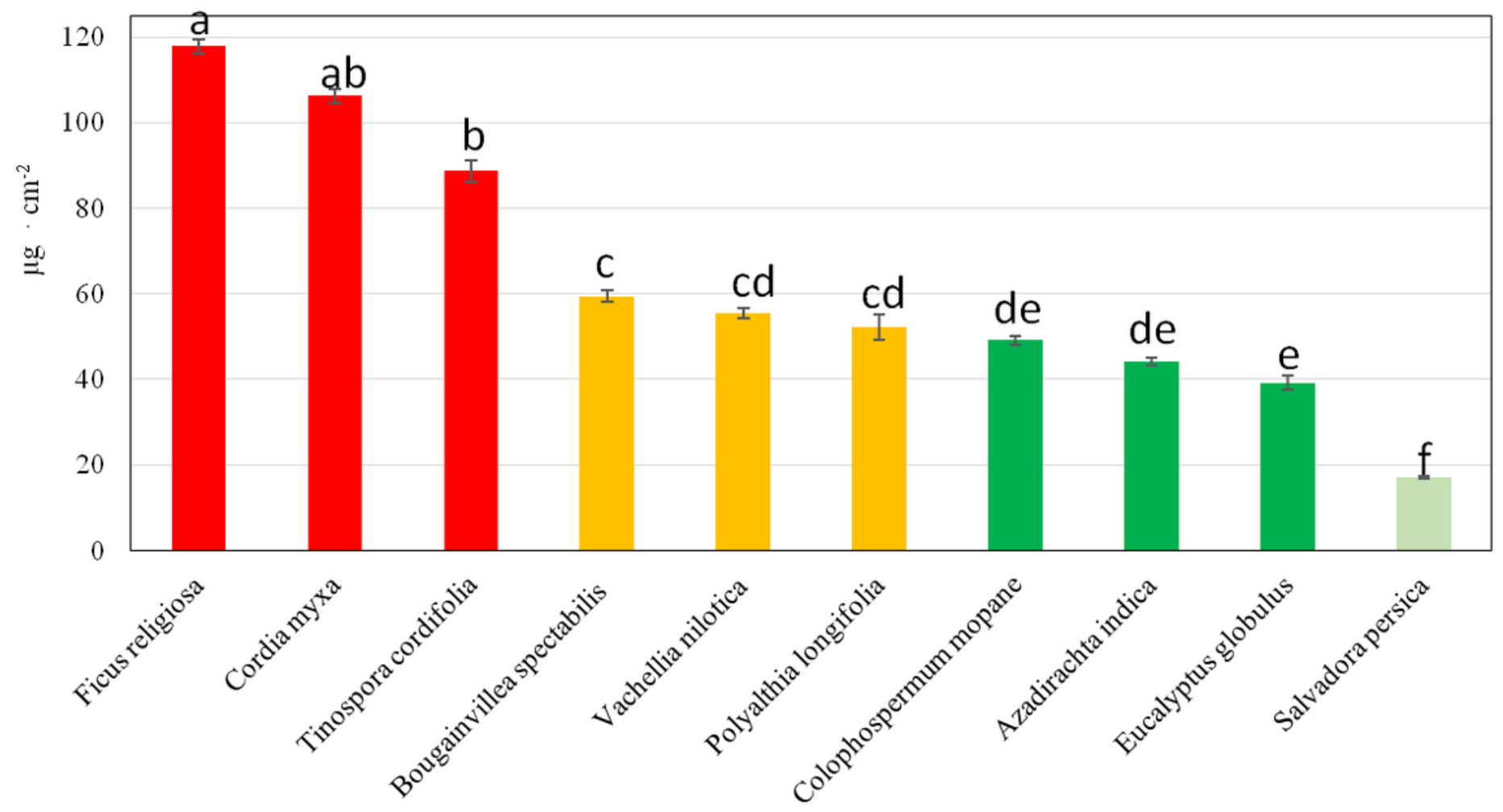

Figure 2

Total PM accumulation on the leaves of 10 plant species. Data are mean $\pm S E, n=4$. Different letters indicate statistical significance $(P<0.05)$

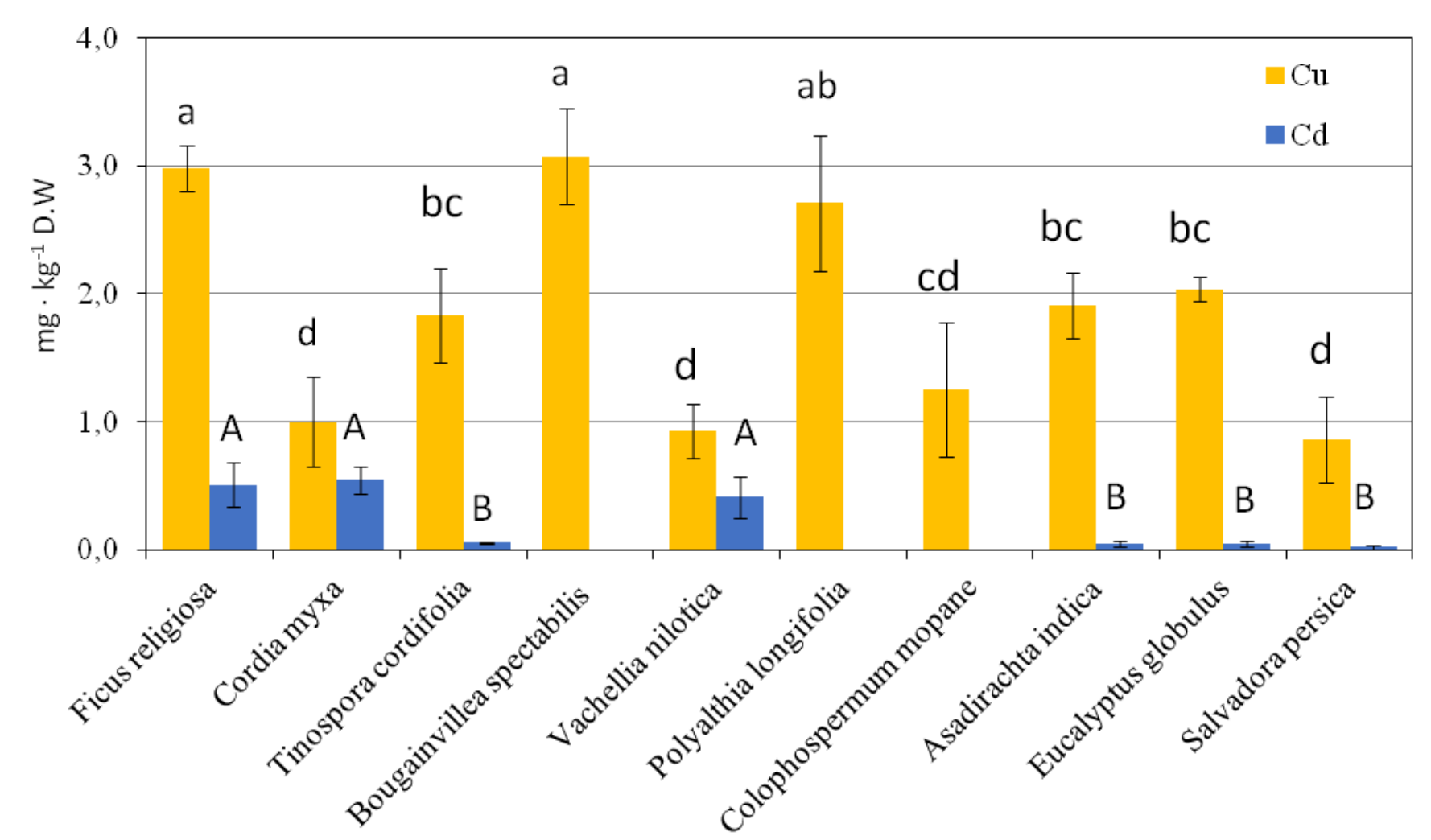

Figure 3 
Concentrations of $\mathrm{Cu}$ and $\mathrm{Cd}$ in the foliage of 10 plant species. Data are mean $\pm S E, n=2$. Different lowercase letters for $\mathrm{Cu}$ and capital letters for $\mathrm{Cd}$ indicate a statistical significance $(P<0.05)$ between species separately for each heavy metal.

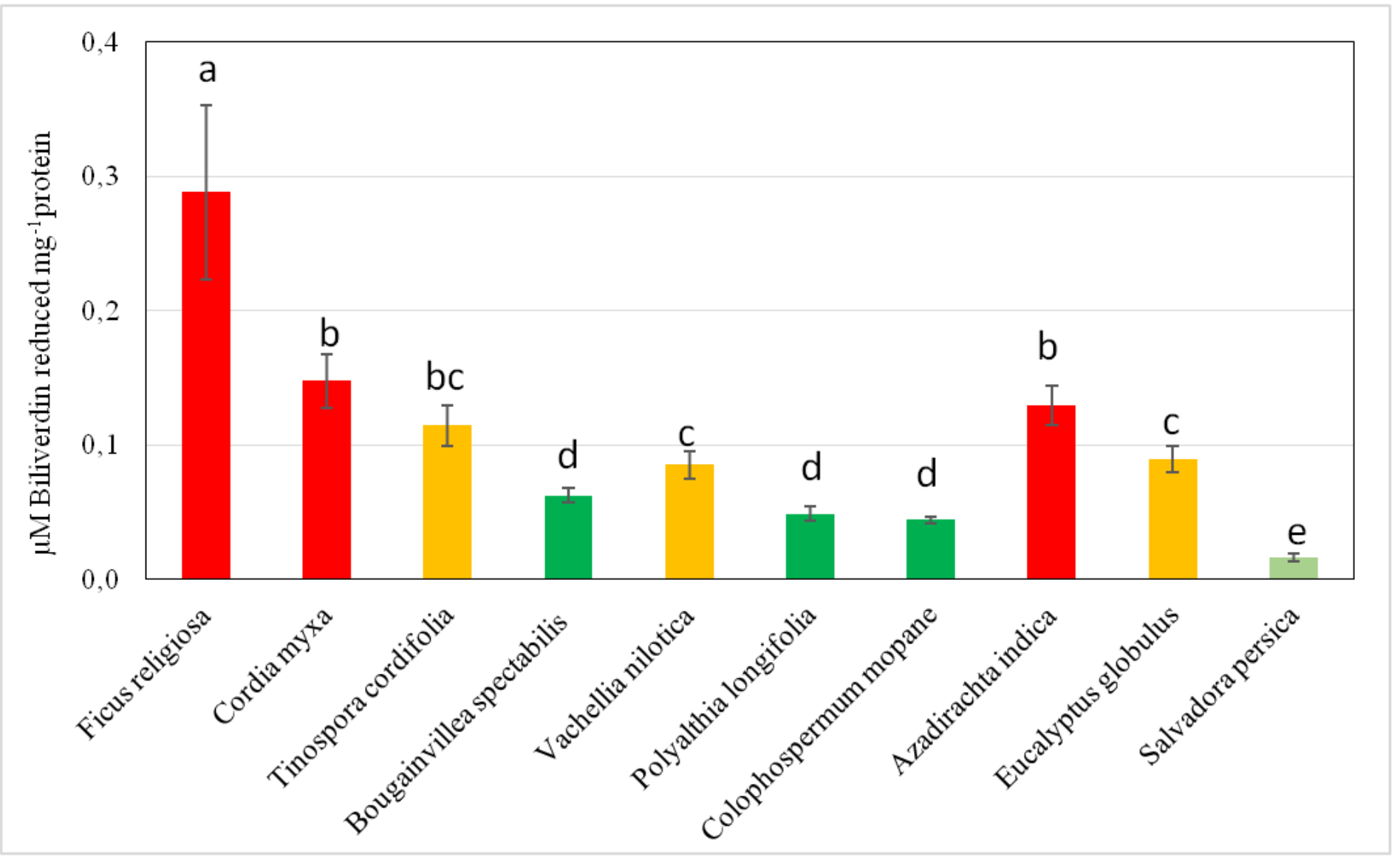

\section{Figure 4}

Heme oxygenase activity in the leaves of 10 plant species. Data are means $\pm S E, n=3$. Different letters indicate a statistical significance $(P<0.05)$. 